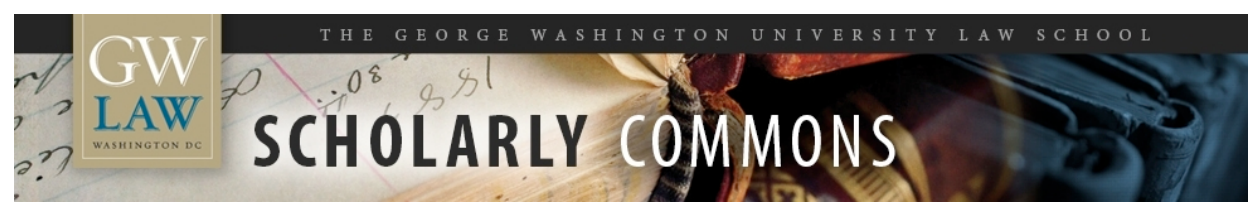

\title{
Comment on Intellectual Property, Concentration and the Limits of Antitrust in the Biotech Seed Industry
}

\author{
F. Scott Kieff \\ George Washington University Law School, skieff@law.gwu.edu
}

Follow this and additional works at: https://scholarship.law.gwu.edu/faculty_publications

Part of the Law Commons

\section{Recommended Citation}

Kieff, F. Scott, "Comment on Intellectual Property, Concentration and the Limits of Antitrust in the Biotech Seed Industry" (2009). GW Law Faculty Publications \& Other Works. 554.

https://scholarship.law.gwu.edu/faculty_publications/554

This Article is brought to you for free and open access by the Faculty Scholarship at Scholarly Commons. It has been accepted for inclusion in GW Law Faculty Publications \& Other Works by an authorized administrator of Scholarly Commons. For more information, please contact spagel@law.gwu.edu. 


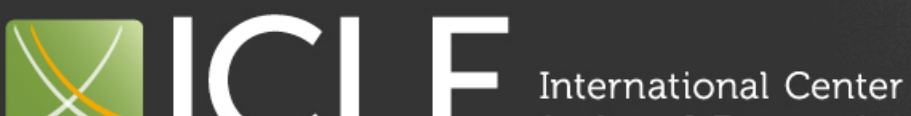 \\ for Law \& Economics}

In Honor of

DOJ / USDA Workshops

Comments Regarding Agriculture and Antitrust Enforcement Issues in Our 21st Century Economy

\section{Comment on Intellectual Property, Concentration and the Limits of Antitrust in the Biotech Seed Industry}

\section{INTERNATIONAL CENTER FOR LAW AND ECONOMICS}

\section{F. Scott Kieff}

George Washington University School of Law

Hoover Project on Commercializing Innovation

Geoffrey A. Manne

International Center for Law and Economics

Lewis \& Clark Law School

Michael E. Sykuta

University of Missouri Division of Applied Social Sciences

Contracting and Organizations Research Institute

Joshua D. Wright

George Mason University School of Law

International Center for Law and Economics 


\section{Introduction}

Biotech seeds have become an enormously-valuable part of the food supply in the US and abroad. A substantial portion of soybeans, corn, cotton and other agricultural products grown in the US are derived from genetically-modified seeds. The genetic traits that give these seeds their value-traits that confer resistance to herbicide and high yields, for example-are often developed by large agribusiness companies, with enormous research and development investments. The process is technologically-advanced, time- and moneyintensive, a risky investment, and subject to various layers of regulation. The process of developing a new seed variety can take 15 years and require hundreds of millions of dollars of investment. Regulations from the USDA, the FDA and the EPA can slow or halt the process, and international trade regulations (particularly from countries that ban or severely restrict importation of GMOs) complicate the control and the commercialization of the final products.

In part for these reasons, the biotech seed industry-like all segments of the US agricultural industry-has seen a substantial increase in concentration. Large scale is of obvious benefit to companies engaged in massively expensive R\&D programs that can achieve economies of scale and thus lower costs. Meanwhile, there are also likely other vertical efficiencies associated with contractual arrangements between various players in the transgenic supply chain:

Vertical efficiencies such as reduced transactions costs and coordination achieved by exploiting the complementarities between traits and traited seed assets can also reduce costs. Closer, more precise coordination between levels in the transgenic supply chain may result in more efficient creation of new transgenic varieties in increasingly differentiated product markets. ${ }^{1}$

Thus it is not surprising that the period of increasing innovation has been accompanied with an increase in concentration as innovating firms assembled the necessary, complementary assets to develop and commercialize their innovations, often through vertical and horizontal mergers and acquisitions. ${ }^{2}$ The remarkable gains in biotech seed development since the industry's infancy less than 20 years ago, along with the complexities of the industry and our limited understanding of the economic significance of

\footnotetext{
1 Diana L. Moss, "Transgenic Seed Platforms: Competition Between a Rock and a Hard Place?," American Antitrust Institute White Paper (October 23, 2009), available at http://www.antitrustinstitute.org/Archives/seed.ashx.

${ }^{2}$ Id. at Figure 2. While Moss happens to conclude that this inverse correlation is a surprise and struggles to find explanations for the seeming contradiction, the proffered explanations are unpersuasive (or irrelevant). See Nicholas Kalaitzandonakes \& Bruce Bjornson, Vertical and horizontal coordination in the Agrobiotechnology industry: Evidence and implications, 29 J. AG. AND APPL. ECoN. 129 (1997) for a more relevant analysis of industry forces.
} 
organizational choices in the industry, should counsel strongly against hasty antitrust intervention in the industry. Consumers enjoy significant benefits from innovation that must be considered before responding too quickly or improperly to complaints about increased concentration, especially if the complaints come merely from competitors.

\section{The Economic Benefits of Intellectual Property}

\section{a. Incentives to Innovate}

Intellectual property rights provide important incentives for getting inventions made (inventing) and widely put to use (the overall process of innovation, including invention and its use). ${ }^{3}$ When intellectual property rights are characterized by predictable legal rules governing validity, enforceability, and contracting, they help get deals done among the diverse set of complementary users of intellectual assets that are needed to bring them to market, including inventors, venture capitalists, managers, laborers, manufacturers, distributors, etc. At the same time, they produce incentives to develop alternative technologies as well as improvements and other derivative uses. In economic terms, intellectual property rights solve coordination problems and decrease transaction and information costs to bring to market new technologies and new business models, thereby increasing competition and access, as well as jobs and overall economic growth.

The primary focus of the economic literature has been on the role of intellectual property in providing direct incentives to inventors (or creators) to invent (or create). ${ }^{4}$ This function is illustrated by considering the sale of ideas in the absence of enforceable intellectual property rights. The sale of an idea requires disclosure to the potential buyer, who will have a difficult time reaching a decision to pay a sufficiently high price until the idea can be fully evaluated. In the absence of enforceable intellectual property rights, the potential buyer - now with knowledge of the idea - has no incentive to purchase or license the idea. This possibility deters the seller from disclosing the idea in the first place and is known in the economic literature as the Arrow Information Paradox after the work that led in part to the awarding of the Nobel Prize in economics to Professor Ken Arrow. ${ }^{5}$ Enforceable property rights solve this problem by allowing the seller to disclose the idea without fear that the idea will be legally appropriated without compensation, and by allowing the prospective buyer to avoid having to post a bond or otherwise somehow credibly commit to paying later if he decides the idea is of value. Property rights in the idea thereby help provide important incentives to not only produce the idea in the first place, but also to disclose it to others.

\footnotetext{
${ }^{3}$ See generally William LANDES \& Richard A. POSNER, THe ECONOMIC STRUCTURE OF INTELLECTUAL PROPERTY LAW (2003).

${ }^{4}$ Id.

${ }^{5}$ For Arrow, the "fundamental paradox" of information is that "its value for the purchaser is not known until he has the information, but then he has in effect acquired it without cost." KENNETH J. ARROW, ESSAYS IN THE THEORY OF RISK-BEARING 152 (1971).
} 
A second and related focus of the economic literature is the optimal tradeoff between these direct incentives to invent and the ability of others to put the invention to use. ${ }^{6}$ Because ideas have the attributes of a public good (use of the idea by one person does not prevent others from also using the idea), static efficiency considerations dictate the widespread use of the idea. The creation of incentives to produce inventions and other ideas through property rights can result in above marginal cost pricing of ideas, which can in turn inefficiently limit access to and use of the same inventions, from what economists consider a static welfare perspective. This implies a trade off between incentives to invent and the static effects on use or access. This incentive-access tradeoff explains in general why limitations on both the scope and length of intellectual property rights are appropriate. ${ }^{7}$ The tradeoff is most acute when intellectual property rights confer significant market power to the holder of these rights.

A third focus of the economic literature is that intellectual property rights can facilitate transactions by lowering transaction and information costs. Well defined intellectual property rights facilitate both the licensing and sale of intellectual assets. Such rights also allow others to avoid infringement of intellectual property rights by using non-infringing substitutes or by entering a licensing or assignment contract with the owner. ${ }^{8}$ When intellectual property rights are not well defined, they may instead raise transactions and information costs. ${ }^{9}$

\section{b. Facilitating Commercialization}

\section{i. The Role of Intellectual Property Law}

IP rights generally operate as rights of exclusion. As a result, many worry that their enforcement will result in too little use of whatever they cover. Further, the subject matter IP rights cover generally is understood to show prototypical attributes of public goods in that it is nonrivalrous and nonexclusive. Classic work by Harold Demsetz, however, has shown that private producers can produce and sell an efficient level of public goods under appropriate conditions. ${ }^{10}$ Intellectual property law provides just such conditions.

Getting an invention made and bringing it to market require coordination among its many complementary users, including developers, managers, laborers, other technologists, financiers, manufacturers, marketers, and distributors. Patents help achieve this socially constructive coordination by allowing those various actors to interconnect with each other like modules of a larger system. The underlying mechanism depends in at least three

\footnotetext{
${ }^{6}$ See, e.g., LANDES AND POSNER, supra note 3, at 11.

${ }^{7}$ Edmund W. Kitch, Elementary and Persistent Errors in the Economic Analysis of Intellectual Property, 53

VAND. L. REV. 1727 (2000).

8 F. Scott Kieff, Property Rights and Property Rules for Commercializing Inventions, 85 MINN. L. R. 697 (2001).

${ }^{9}$ See, e.g., James Bessen \& Michael J. Meurer, Patent Failure: How Judges, Bureaucrats, and Lawyers Put InNOVATORS AT Risk (2009); MichaEl A. HelleR, THE GRidlock EConomy (2008); Michael A. Heller \& Rebecca A. Eisenberg, Can Patents Deter Innovation? The Anticommons in Biomedical Research, 280 SCIENCE 698 (1998). ${ }^{10}$ Harold Demsetz, Toward a Theory of Property Rights, 57 Am. Econ. Rev. 347, 354 (1967); Harold Demsetz, The Private Production of Public Goods, 13 J.L. \& ECoN. 293 (1970).
} 
fundamental ways on the expectation that patents will be enforced with strong property protection and that whatever contracts are struck surrounding those patents will be enforced on their own terms as well. First, the credible threat of exclusion associated with a published patent acts like a beacon in the dark, drawing to itself all those interested in the patented subject matter. The beacon effect motivates those diverse actors to interact with one another and with the patentee, starting conversations among the relevant parties. Second, the widespread expectation that the patent and any resulting contracts will be enforced motivates each of these parties to reach agreements with one another over the use and deployment of the technology. That bargaining effect falls apart if the parties are unsure that the patent and the related contracts will be enforced; if the patent and related contracts are seen as not being enforced, there is significantly less interest in reaching agreement ex ante. Thus the fear of weak enforcement creates a disincentive for the necessary parties to work together at the outset. Finally, patent protection allows each of these parties to appropriate the returns to (rival) inputs to developing and commercializing innovation - labor, lab space, and so forth-without the law having to trace the relative contributions of these multifarious inputs. Instead patents form a platform on which coordination and development can take place. ${ }^{11}$

\section{ii. The Role of Licensing}

The types of contractual restrictions that implement a limited patent license are not foreign to property or contract law generally, are commonly used throughout consumer society, and are even more common in transactions among large commercial parties. Consider, for example, a typical lease for the rental of real or personal property containing a restriction against subleasing: Even the general view favoring the ability to assign and delegate rights and obligations in intangible assets like contracts fully respects the power of restrictive terms in an underlying contract governing whether or how such third-party rights in it can be created. Consider the ways in which the risk profiles of a short term and long term tenant are different in a range of ways that can impact the price and other terms of a lease in a range of ways. For example, a short term tenant may trigger higher transaction costs of preparing the apartment between tenants and higher risk that the apartment will sit unrented, as well as higher costs of negotiating multiple contracts for a longer term. While at the same time a long term tenant may be more difficult to evict, more difficult to charge a higher rental price, or more likely to surreptitiously sublease. Because courts recognize that the parties will be best able to determine which terms best meet their needs given their own particular situation, courts generally enforce these contracts on their own terms absent ordinary contract law defenses to formation (such as fraud, duress, mistake, unconscionability, etc.). For similar reasons, courts generally do, and should, let parties to patent licenses strike whatever terms they select, including field of use and other restrictions.

\footnotetext{
11 Henry E. Smith, Intellectual Property as Property: Delineating Entitlements in Information, 116 YALE L.J. 1742 (2007); F. Scott Kieff, On Coordinating Transactions in Information: A Response to Smith's Delineating Entitlements in Information, 117 YALE L.J. POCKET PART 101 (2007), http://thepocketpart.org/2007/10/10/kieff.html
} 
The ability to license IP with restrictions, far from leading to a reduction in the social value of patented ideas, actually increases the ability of the patent holder to license them to a wider range of licensees, usually with different licensees electing to pay different prices depending on the restrictions, with unrestricted deals costing the most. And of course price is often not the only important term in these deals, otherwise the documents underlying the deals would be incredibly short, primarily focused on patent number and price. Instead, the deal documents are very long because the parties are able to use the foundation of a license to a predictably enforced intellectual property right as a platform on which to build a very significant set of contractual arrangements often allocating a range of technological know how, risks, rewards, and other highly valuable non-patent assets. The net effect is that, although each individual license may contain restrictions on use, there are more licenses and more licenses obtained on optimal terms by diverse licensees, leading to an overall increase in social welfare derived from patented innovations.

\section{First Principles of Antitrust Treatment of Intellectual Property 12}

Antitrust analysis of intellectual property is, as Judge Richard Posner has concluded, "sufficiently informed by economic theory, to cope effectively with the distinctive-seeming antitrust problems that the new economy presents."13 Thus it is generally well-accepted that the fundamental first principles guiding antitrust analysis generally should apply with equal force to industries involving intellectual property. These first principles include understanding that monopoly power is a necessary precondition of any potential monopolization violation, that most business conduct involves efficiency justifications, that it is difficult to distinguish pro-competitive conduct from anticompetitive conduct, and that the potential for costly false positives warrants a humble approach to antitrust intervention that requires plaintiffs to present persuasive evidence of actual anticompetitive effect. While these principles are well established in Supreme Court antitrust jurisprudence and modern agency enforcement approaches, the primary challenge that arises in such antitrust cases is to avoid the temptation to treat them differently.

Courts that adopt special approaches to address matters at the periphery of IP law run the risk of crafting judicial doctrines that inappropriately override well-established bodies of law that are informed by longstanding judicial and scholarly thought and consideration of each area. Put simply, when considering disputes and transactions at the periphery of IP law where it intersects other bodies of law, some decision-makers too often take select principles from each body of law out of their larger context and legal framework, while ignoring other basic features and principles of relevant legal regimes. For example, some of the now discredited cases applying the so-called doctrine of patent misuse overlook a

\footnotetext{
12 This section is drawn from F. Scott Kieff \& Troy A. Paredes, The Basics Matter: At the Periphery of Intellectual Property, in LISA N. TAKEYAMA \& WENDY J. GORDON, DEVELOPMENTS IN THE ECONOMICS OF COPYRIGHT: RESEARCH AND ANALYSIS (2005) 159.

13 Richard A. Posner, ANTitrust LaW 256 (2d edition 2001).
} 
number of considerations involving vertical restraints of trade that drive the present conclusion under antitrust law that few vertical restraints are anticompetitive and that many are in fact procompetitive. Such selective picking and choosing from concepts across multiple disciplines not only creates uncertainty, but, as suggested, it often gets things wrong because it involves decision-making that is conducted without the benefit of the full diversity of contrasting goals and ideas that are ordinarily discussed and considered when decisions ordinarily are made within each particular discipline.

The same dynamic holds in the application of IP principles in antitrust, and there is a reflexive intuition among many courts and commentators to condemn as anticompetitive conduct relating to the use of IP that would be likely or even presumptively legal under the antitrust laws in the absence of IP. This latter dynamic is particularly problematic as it threatens substantial costs, both from the likelihood and the incidence of error.

\section{a. Error Cost Framework of Modern Antitrust ${ }^{14}$}

Given the fundamental difficulty of identifying the competitive consequences of business practices generally, and innovations especially, concern with the social costs of these errors ("error costs") have been a mainstream consideration in antitrust policy discourse for the last quarter century and have played a central role in Supreme Court decisions and the design of agency enforcement policies.

As even critics of concentration in the genetically-modified seed industry note, "[t]he shift from separate ownership of agricultural biotechnology and seed assets to the development of transgenic seed platforms has ushered in a host of competitive issues that are still relatively new to antitrust enforcement."15 The concern is that application of antitrust analysis, rooted in stylized economic models--"possibility theorems"-heavily dependent on a narrow set of assumptions will result in erroneous enforcement in the face of this novelty. A modest safeguard to protect against this concern of "false positives," is an approach to antitrust that requires a strong demonstration of actual anticompetitive effect as a precondition for a monopolization violation.

Judge Easterbrook's influential Limits of Antitrust ${ }^{16}$ introduced the antitrust community to thinking rigorously about the relationship between antitrust errors, their social costs, and the design of antitrust rules. The key policy tradeoff, Easterbrook explained, was that between Type I ("false positive") and Type II ("false negative") errors. Table 1 presents a two by two matrix laying out the types of errors that occur in antitrust litigation. ${ }^{17}$

\footnotetext{
14 This section is derived from Geoffrey A. Manne \& Joshua D. Wright, Innovation and the Limits of Antitrust, _J. Comp. L. \& EcoN. __ (forthcoming 2010).

15 “Transgenic Seed Platforms: Competition Between a Rock and a Hard Place?" supra note 1.

16 Frank H. Easterbrook, The Limits of Antitrust, 63 TEXAS L. REV. 1 (1984).

17 Table 1 originally appears in David S. Evans \& Jorge Padilla, Neo-Chicago Approach to Unilateral Practices, 72 U. CHI. L. REV. 73 (2005).
} 
Table 1: Possible Errors in the Antitrust Assessment of Business Practices

\begin{tabular}{|l|l|l|}
\hline Competitive Impact & Illegal & Legal \\
\hline Harmful to Competition & $\begin{array}{l}\text { Percent of cases } \\
\text { correctly condemning } \\
\text { anticompetitive } \\
\text { practices }\end{array}$ & $\begin{array}{l}\text { Percent of cases falsely } \\
\text { absolving anticompetitive } \\
\text { practices } \\
\text { ("false negatives") }\end{array}$ \\
\hline Not Harmful to Competition & $\begin{array}{l}\text { Percent of cases falsely } \\
\text { condemning legitimate } \\
\text { practices } \\
\text { ("false positives") }\end{array}$ & $\begin{array}{l}\text { Percent of cases correctly } \\
\text { absolving legitimate } \\
\text { practices }\end{array}$ \\
\hline
\end{tabular}

From simple legal and economic assumptions, Easterbrook provided a powerful framework to think about the optimal design of antitrust rules in the face of expected errors. The assumptions were as follows: (1) both types of errors were inevitable in antitrust cases, because of the difficulty in distinguishing efficient, pro-competitive business conduct from anticompetitive behavior; ${ }^{18}(2)$ the social costs associated with Type I errors would generally be greater than the social costs of Type II errors because market forces offer at least some corrective with respect to Type II errors and none with regard to Type I errors, or as Easterbrook articulated it, "the economist's system corrects monopoly more readily than it corrects judicial [Type II] errors;"19 and (3) optimal antitrust rules will minimize the expected sum of error costs subject to the constraint that the rules be relatively simple and reasonably administrable.

Immediately one can see the importance of the fundamental insight from the Limits of Antitrust that Type I errors are likely to be more costly than Type II errors because market forces place some constraints on the latter but not the former. Indeed, this insight becomes more and not less important as our collective economic wisdom about a new business practice decreases-when, in other words, a challenged practice or setting is innovative. All things equal, the error-cost framework calls for a more interventionist antitrust rule when Type II error costs are higher, there are strong priors that the given practice is anticompetitive, and theory and evidence suggest a strong likelihood that the practice is anticompetitive. ${ }^{20}$

\footnotetext{
18 There are really two separate points here. The first is the inevitability of errors with decision by legal rule generally. See Easterbrook, supra note 16, at 14-15 (reiterating that "one cannot have the savings of decision by rule without accepting the costs of mistakes."). The second point is that the likelihood of antitrust error depends crucially on the development of economic science to produce techniques and methods by which we can successfully identify conduct that harms consumers. See also Frank H. Easterbrook, Workable Antitrust Policy, 84 Mich. L. REV. 1696 (1986).

19 Easterbrook, supra note 16, at 15.

${ }^{20}$ Multiple academics review the existing theory and evidence on vertical restraints and single firm conduct more generally and uniformly conclude that the practices at issue are generally pro-competitive and that antitrust rules should "slant" towards requiring plaintiffs to demonstrate clear anticompetitive effect before
} 
Innovation creates special opportunity for antitrust error in two important ways. The first is that innovation by definition generally involves new business practices or products. Novel business practices or innovative products have historically not been treated kindly by antitrust authorities. From an error cost perspective, the fundamental problem is that economists have had a longstanding tendency to ascribe anticompetitive explanations to new forms of conduct that are not well understood. As Nobel Laureate Ronald Coase described in lamenting the state of the industrial organization literature:

if an economist finds something-a business practice of one sort or another-that he does not understand, he looks for a monopoly explanation. And as in this field we are very ignorant, the number of understandable practices tends to be very large, and the reliance on a monopoly explanation, frequent. $^{21}$

The critical link between antitrust error and innovation is that, relative to non-innovation cases, the stakes are higher. While the empirical literature does not contain reliable information on the relative magnitudes of Type I and Type II error costs, the wellestablished empirical link between innovation and economic growth tells us that the stakes of error are much higher. One reason that antitrust intervention in the face of innovative products is (deservedly) uncommon is that new goods are generally quite valuable, and the cost to deterring the introduction of new goods and expenditures on innovation, both of which are potentially costly and extremely risky, is high. ${ }^{22}$ This effect is perhaps magnified in the agricultural sector where the consequences of undue deterrence may be hunger and starvation among disadvantaged segments of the population.

\section{b. Patents and Antitrust Market Power}

The intersection of IP and antitrust is thus fraught with peril. The risks of error are high given both the inherent uncertainty of the economic import of conduct surrounding the development and commercialization of innovations, as well as the possibility of mistakes from melding principles from two distinct areas of law. The costs are likewise substantial,

condemning finding violations. See, e.g., James Cooper, et al., Vertical Antitrust Policy as a Problem of Inference, 23 INT'L J. InDUS. ORG. 639 (2005); Francine Lafontaine and Margaret Slade, Exclusive Contracts and Vertical Restraints: Empirical Evidence and Public Policy, in HANDBOoK of ANTITRUST ECONOMICS (Paolo Buccirossi, ed., 2009); Daniel P. O'Brien, The Antitrust Treatment of Vertical Restraints, in REPORT: The Pros AND CONS OF VERTICAL RESTRAINTS 40 (2008), available at

http://www.konkurrensverket.se/upload/Filer/Trycksaker/Rapporter/Pros\&Cons/rap_pros_and_cons_verti cal_restraints.pdf.

${ }^{21}$ Ronald Coase, Industrial Organization: A Proposal for Research, in POLICY ISSUES AND RESEARCH OPPORTUNITIES IN INDUSTRIAL ORGANIZATION (Victor R. Fuchs, ed., 1972). For more modern critiques of the industrial organization literature in the same vein, see Timothy J. Muris, Economics and Antitrust, 5 GEO. MASON. L. REv. 303 (1997), Bruce H. Kobayashi, Game Theory and Antitrust: A Post Mortem, 5 GEo. MASON L. Rev. 411 (1997); Evans and Padilla, supra note 17.

22 See generally The Economics of NEW Goods 209 (Timothy F. Bresnahan \& Robert J. Gordon, eds., 1997); see also Easterbrook, supra note 16. 
as the dynamic consequences of stifling innovation magnify throughout an industry and the economy as a whole.

It is often said that patents and antirust are two sides of the same coin, with patents conferring limited monopolies for the sake of the incentives they confer, and antitrust reining in monopolies for the sake of the deadweight loss they impose. But this view of the patent/antitrust dichotomy is problematic. While patents do confer some exclusive rights over particular patentable innovations, competition can and does occur in IP-intensive industries because patent grants, when properly circumscribed, confer exclusivity only over particular processes or designs, not entire fields of innovation. In the biotech seed industry, for example, several companies have competing patents and competing products that accomplish the same overall function from the perspective of the market, even if they do so via technologically- and patently-distinct approaches. The right to exclude unauthorized use of one of these underlying processes does not preclude competition, but rather encourages it.

At the same time, as we have discussed, patented innovations are monetized primarily through licensing and, as is common in the biotech seed industry, even through licensing to competitors. To the extent that patent grants incentivize the dissemination of ideas through licenses, the claim of monopoly exclusion resulting from patents is a difficult one.

Antitrust law has largely reflected these ideas, and thus patents do not presumptively confer market power on their holders, nor are licensing restrictions-properly viewed as contractual terms necessary to the efficient distribution of innovations-presumptively suspect. $^{23}$

\section{i. Patents Do Not Presumptively Create Market Power}

Modern antitrust courts, enforcement agencies and scholars have emphasized a desire to ground policy in the empirical realities of real world markets. The Supreme Court has expressed a similar preference for antitrust rules that reflect empirical reality over the past several decades which have been marked by a shift away from formalistic rules and toward economically-informed effects-based analysis. The Supreme Court's decision in Independent Ink represents an important step forward in this regard. ${ }^{24}$ In Independent Ink, the Court rejected the longstanding presumption of antitrust market power in tying cases involving patented goods. The decision is unequivocally good for consumers and eminently sensible. The presumption is at odds with the longstanding consensus among

\footnotetext{
${ }^{23}$ It was not always this way, and the DOJ's infamous "Nine No-Nos" of patent licensing, promulgated in the 1970s, treated many licensing practices with deep suspicion. The Nine No-Nos have been thoroughly debunked and repudiated since. See Abbott B. Lipsky, Jr., Deputy Assistant Attorney Gen., U.S. Dep't of Justice, Current Antitrust Division Views on Patent Licensing Practices, Remarks Before the American Bar Association Antitrust Section (Nov. 5, 1981), reprinted in 4 Trade Reg. Rep. (CCH) I 13,129 (abandoning application of the Nine No-Nos).

${ }^{24}$ Illinois Tool Works Inc. v. Independent Ink, Inc., 126 S. Cт. 1281 (2006), rev'g 396 F.3d 1342 (Fed. Cir. 2005).
} 
antitrust scholars, ${ }^{25}$ Congress, ${ }^{26}$ and the antitrust agencies ${ }^{27}$ that patents do not confer antitrust monopoly power. There is virtually no authority defending the proposition, and rightly so.

Justice Stevens' opinion for the unanimous Court should be applauded for taking an important step towards aligning a perplexing and muddled tying jurisprudence with economic sense and empirical reality. The opinion is an excellent example of how modern analysis at the intersection of intellectual property and antitrust has substituted away from formalistic presumptions of anticompetitive effect of business arrangements when patents are present toward a more rigorous and effects-based analysis incorporating the insights of economic theory and empirical evidence. Indeed, the empirical reality is that the modern economy involves markets nearly universally characterized by product differentiation and competitive price discrimination. The link between these two points is clear: the patent right guarantees only the absence of perfect substitutes, and while this guarantee says nothing about monopoly power - the ability to control market prices - it is all that is required to price discriminate. The opinion therefore goes a long way, but arguably not the entire distance, ${ }^{28}$ to establish the proposition that price discrimination is a normal part of the competitive process in the modern economy.

Even more important than the consumer benefits of overturning an anachronistic and economically perverse antitrust rule for business tying arrangements involving patents is that Independent Ink is consistent with a more general trend in modern Supreme Court antitrust jurisprudence toward doctrine that is sensitive to the social costs imposed by chilling the incentive to innovate and commercialize innovation, and not bound by simplistic and wrongheaded approaches to competition policy that would leap from the mere presence of patent rights to presumptions that business arrangements otherwise known to generate consumer benefits are presumptively harmful.

\section{ii. Antitrust and IP Encourage Dynamic Efficiency}

The tensions between antitrust and intellectual property have been a frequent subject of debate by legal scholars, economists and courts. Conventional wisdom was that antitrust promotes competition and patent law promotes monopoly, and therefore, the two are properly viewed as serving conflicting goals. For much of the twentieth century, courts and enforcement agencies viewed intellectual property as creating a monopoly and

\footnotetext{
25 See, e.g., 10 Philip E. AREedA Et AL., ANTItrust LAW 9 1737a (2d ed. 2004); 1 HERbert HovenkAmp ET AL., IP AND

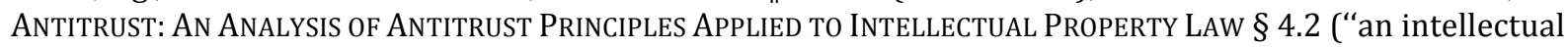
property right does not confer a monopoly"); RICHARD A. POSNER, ANTITRUST LAW 97-98 (2d ed. 2001) ("most patents confer too little monopoly power to be a proper object of antitrust concern").

2635 U.S.C. $§ 271(d)(4)$, (5) (amending patenting laws to mandate proof of market power in the tying product in the patent misuse context).

27 U.S. DePartment of Justice AND FEDERAL TRAde Commission, ANTITRUST GUIDELINES FOR THE LiCENSING OF INTELLECTUAL PROPERTY $§ 2.2$ (Apr. 6, 1995) (enforcement agencies will "not presume that a patent, copyright, or trade secret necessarily confers market power upon its owner").

${ }^{28}$ See Joshua D. Wright, Missed Opportunities in Independent Ink, 2005-06 Cato SuPREME Court RevieW 333

(2006).
} 
antitrust case law encouraged that presumption. Through the 1970's, the infamous "Nine No-No's" approach to intellectual property embedded that skepticism into enforcement decisions and judicial thinking about intellectual property and antitrust.

Economic learning soon would change matters. The Antitrust Modernization Committee Report ("AMC Report") notes the dramatic reversal that would take place over the next several decades:

The influence of economic learning about the competitive benefits of intellectual property and the potential efficiencies of intellectual property licensing and other conduct reversed this trend. In 1981 the Chief of the Intellectual Property Section of the Antitrust Division explained that because patents increase the reward for research and development, inventions are produced that otherwise would not have come about (or would not have come about as quickly); in those cases, "the availability of a patent [serves] only to benefit competition - to make additional or less expensive choices available to consumers." In 1981 officials from the DOJ renounced the Nine No-Nos. The 1995 Antitrust Guidelines for the Licensing of Intellectual Property (DOJ/FTC IP Guidelines), issued jointly by the DOJ and the Federal Trade Commission (FTC), take the view that "intellectual property licensing $\ldots$ is generally procompetitive" and should be examined under the rule of reason. ${ }^{29}$

The AMC Report goes on to accurately capture the modern consensus on the relationship between antitrust and intellectual property rights, noting that:

Courts and the antitrust agencies in recent decades have evidenced a greater appreciation of the importance of intellectual property in promoting innovation and, accordingly, the need to incorporate this recognition into a dynamic analysis of competitive effects. Witnesses and commenters remarked there is an improved understanding that antitrust law and patent law are complementary, with both seeking to encourage innovation and competition. ${ }^{30}$

Indeed, economic learning would teach that any conflict between antitrust and intellectual property arises only when analyzing a single aspect of the use / creation tradeoff without regard to the overall impact on social welfare. ${ }^{31}$ Modern consensus is that antitrust and intellectual property rights are not only compatible, but complementary doctrines with the shared economic goal of maximizing innovation and dynamic efficiency. Perhaps the most obvious examples of how antitrust and intellectual property rules adapt to achieve this goal is the immunity that antitrust provides for monopoly in cases when it results in greater

\footnotetext{
${ }^{29}$ Antitrust Modernization Committee Report And Recommendations 37 (2008) (citations omitted).

30 ID. at 38-39.

${ }^{31}$ See Bruce H. Kobayashi and Michele Burtis, Intellectual Property and Antitrust Limits on Contract in DynAmiC Competition And Public Policy: Technology, InNovation And Antitrust Issues 229 (J. Ellig, ed., 2001).
} 
output than would a fragmented industry because of economies of scale or allowing the innovating monopolist the fruits of charging the monopoly price. ${ }^{32}$

Thus, the modern antitrust view of the intersection of antitrust and intellectual property rules is that they "are actually complementary, as both are aimed at encouraging innovation, industry, and competition." 33 For example, former Federal Trade Commission Chairman Muris has explained that when "properly understood, IP law and antitrust law both seek to promote innovation and enhance consumer welfare." 34 In light of this recognition of the complementary goals of antitrust and intellectual property to maximize dynamic efficiency and innovation, the primary challenge in this area is to design rules that foster competition and innovation and provide a backstop which prohibits clearly socially undesirable activity without deterring innovation.

One powerful example of this approach has been in the shift in antitrust treatment of licensing from the aforementioned Nine No-No approach of prohibiting as per se illegal various licensing practices to the modern rule of reason approach. ${ }^{35}$ In addition to elimination of these per se restrictions, and the elimination of the market power presumption in patent tying cases, in the Supreme Court has also relaxed the per se prohibition against minimum resale price maintenance in favor of an effects-based, rule of reason approach that takes into account the economic theory and empirical evidence suggesting that such licensing arrangements are generally pro-competitive. ${ }^{36}$ Overall, these changes in antitrust evaluation of patents and licensing arrangements demonstrate a shift that reflects increased recognition of the social value of patents and contractual arrangements between intellectual property rights holders and licensees.

\footnotetext{
32 See Verizon Communications, Inc. v. Law Offices of Curtis Trinko, LLP, 540 U.S. 398 (2004) ("The opportunity to charge monopoly prices-at least for a short period-is what attracts 'business acumen' in the first place; it induces risk taking that produces innovation and economic growth. To safeguard the incentive to innovate, the possession of monopoly power will not be found unlawful unless it is accompanied by an element of anticompetitive conduct.").

33 See generally, Federal Trade Commission, To Promote Innovation: The Proper Balance of Competition and Patent LaW And Policy 3-9 (October 2003). See also Atari Games Corp. v. Nintendo of Am., 897 F.2d 1572, 1576 (Fed. Cir.1990). See also R. Hewitt Pate, Refusals to Deal and Intellectual Property Rights, 10 GEO. MASON L. REv. 429, 429 (2002) ("Intellectual property and antitrust laws share a common objective - to encourage innovation, industry, and competition.").

34 Timothy J. Muris, Competition and Intellectual Property Policy: The Way Ahead, speech before American Bar Association Antitrust Section, Fall Forum 2 (Nov. 15, 2001), at http://www.ftc.gov/speeches/muris/intellectual.htm.

35 ANTITRUST GUIDELINES FOR THE LICENSING OF INTELLECTUAL PROPERTY, supra note 33 at $§ 3.4$ (1995) (indicating that the agencies will use the rule of reason except for exceptional circumstances warranting per se treatment).

${ }^{36}$ Leegin Creative Leather Products, Inc. v. PSKS, Inc., 551 U.S. 877 (2007).
} 


\section{A Principled Approach to Antitrust Analysis of the Seed Industry}

\section{a. This is a business dispute and not an antitrust issue}

Appropriate error cost analysis requires that we are circumspect before engaging in antitrust enforcement grounded in competitor claims. The inherent uncertainty regarding the economic consequences of conduct, coupled with competitors' poor incentives and the huge costs of error, counsel strongly against antitrust proceedings here.

Antitrust criticism of the US seed industry is often directed at Monsanto, and most of this criticism comes from a handful of competitors. The American Antitrust Institute's white paper, for example, goes to great length to point out increasing concentration in the seed industry, and to try to explain away increases in innovation that have occurred at the same time. But a clear picture of the industry does show that patents are fairly-evenly distributed among competitors, Monsanto has a less-than-dominant share in certain crops (soybeans, for example), Pioneer (DuPont), Monsanto's principle rival has a large and growing share of the soybean and corn biotech seed markets, and that innovation continues apace, with forthcoming (allegedly) advances not only in pest resistance and yield, but in nutritional content, as well.

Meanwhile, Monsanto and DuPont are engaged in a protracted patent dispute, and these antitrust allegations have surfaced significantly only after DuPont raised antitrust counterclaims in that suit. But that dispute is a business dispute between sophisticated parties over the meaning of certain licensing terms. While huge sums are at stake for the competitors, it is not clear that there are social welfare ramifications requiring government intervention. One of the primary criticisms of licensing practices in this industry turns on the ability of a biotech company to negotiate field-of-use restrictions. It is no coincidence that this is the general area of dispute between Monsanto and DuPont.

To the extent that the government sees fit to limit licensing agreements in this area, it has implications for many other sectors of the US economy where IP owners choose to license. The ramifications are significant, as we have suggested: The inability to negotiate wellcrafted licenses with appropriate terms is a disincentive to innovate and, more importantly, commercialize innovations. An all-or-nothing approach to patent licensing will preclude licenses to strong competitors as well as smaller licensees, unable or unwilling to pay for an unrestricted license. And this effect would ripple throughout the economy, deterring a range of procompetitive agreements and forcing a higher degree of vertical concentration in markets where the only alternative to unrestricted licensing is integration. Indeed, precisely because Monsanto's competitors like DuPont also rely on patents and complex licensing terms, in agriculture as well as in other sectors, even these particular competitors would be at risk from such an overreaching antitrust approach. After all, there is often a private or government actor willing to take up the cause of the next smallest competitor, and so on down the line. 
The Green Revolution was one of the most significant humanitarian success stories of all time, built on innovation and ingenuity in the seed industry. As we have progressed, the methods of genetic modification of our food supply have evolved, and, while more is possible, genetic modification is more expensive and more contentious than ever.

Meanwhile, it is precisely this massive innovation and the consequent distribution of intellectual property that will increase both the productivity and quality (along many dimensions) of our crops. The consequences of erroneous deterrence of this progress are enormous, particularly for the poorest and most unhealthy people on the planet. Moreover, deterring the sorts of practices that facilitate innovation in the seed industry would likely deter innovation throughout the economy, with further-reaching effects.

\section{b. Antitrust Analysis of Monsanto's Licensing Restrictions}

Although a full antitrust analysis of licensing practices in the biotech seed industry is beyond the scope of this brief submission, it is important to make a few preliminary remarks here.

The primary complaint against Monsanto is that it employs field-of-use or "anti-stacking" provisions in its licenses to anticompetitive effect. But these claims are not backed by any empirical support, and casual empiricism of the biotech seed industry suggests that both innovation and widespread distribution of benefits to consumers, both farmers and endusers, are common.

Of particular note, according to the USDA's own statistics, in 1988, consumers spent 12.5 percent of their disposable income on food. By 2008 that figure had dropped to roughly 11.6 percent, despite the fact that 2008 witnessed the largest increase in food prices roughly 5.5 percent-since $1990 .{ }^{37}$ Meanwhile, the GAO performed its own study of concentration in various levels of the food marketing chain and concluded that there is no evidence that increased concentration has led to any "adverse affects on commodity or food prices." 38

The complained-of licensing practices, meanwhile, have well-established procompetitive justifications. Field-of-use restrictions are contractual provisions that enable a licensor to divide the rights to its technology, allowing it to allocate production more efficiently among licensees and allowing it to ensure optimal use and branding of its property. As Hovenkamp, Janis and Lemley, make clear: "[e]xcept in unusual circumstances, field-of-use restrictions are not troubling from a competitive perspective." 39

\footnotetext{
${ }^{37}$ Economic Research Service, United States Department of Agriculture, "Briefing Room: Food CPI and Expenditures, Table 8," available at http://ers.usda.gov/Briefing/CPIFoodAndExpenditures/Data/Expenditures tables/table8.htm 38 US Government Accountability Office, "U.S. Agriculture: Retail Food Prices Grew Faster Than the Prices Farmers Received for Agricultural Commodities, but Economic Research Has Not Established That Concentration Has Affected These Trends," GA0-09-746R at p. 3 (June 30, 2009), available at http://www.gao.gov/products/GAO-09-746R.

39 HERBERT HOVENKAMP, ET AL., supra note 25 at $§ 3.3 b 5$.
} 
In the case of Monsanto's licenses, the restrictions, found in licenses to competitors, prevent competitors from developing seed traits with similar functions to the licensed traits and incorporating them together into their own products. One obvious procompetitive intent is to maintain quality control, where a user of the seed would be unable to tell if any bad-or good-functioning was attributable to Monsanto or not. Of particular relevance, Monsanto does not, at least in its contract with DuPont that is the subject of the two companies' ongoing patent dispute and the source of many of these allegations, restrict the stacking of its traits with other traits that perform different functions-only with those traits developed by other companies that purport to perform the same function (in this case, providing resistance to Monsanto's Roundup herbicide).

At the same time, anti-stacking restrictions can help to preserve for a patent holder the ability to compete in other markets, ensuring that its own intellectual property is not used to preclude it from competition in other areas or, in the case of seeds, with newer traits or combinations of traits.

The extent to which Monsanto licenses its intellectual property to competitors is striking, and field-of-use restrictions are essential to this widespread distribution of Monsanto's innovation. "In sum, one would not ordinarily expect output under a license-plus-field-ofuse restriction to be less than output with no license at all, and it could be significantly greater." 40

\section{Conclusion}

One central lesson taught by economics and political science is that there are a set of basic questions we should ask when thinking about how to structure laws for governing market players using legal systems like antitrust and patent. We should recognize that decisions we make about particular cases will impact how future parties will engage in similar situations. We should fully expect that we would not be able to select the true, correct, outcome in every given case with certainty and so should try to be wary of the costs of both types of errors in decision-making: saying no when we should have said yes and saying yes when we should have said no. We should then try to figure out who is best able to provide and evaluate the information needed to make a correct decision and be vigilant of the different ways that interest group politics can drive these decisions. We urge antitrust regulators to be very wary about wading into this area too quickly and too forcefully, if at all.

\footnotetext{
${ }^{40}$ Herbert HovenkAmP, ET AL., IP AND ANTITRUST: An ANALysis of ANTIRUST PRINCIPLES APPLIED to InTELLECTUAL PROPERTY LAW (2004 SUPP.) at §33.4.
} 
F. Scott Kieff is Professor at the George Washington University School of Law in Washington, DC, an academic affiliate of the International Center for Law \& Economics, and a Ray and Louise Knowles Senior Fellow at Stanford University's Hoover Institution. At the Hoover Institution, Professor Kieff directs the Project on Commercializing Innovation, which studies the law, economics, and politics of innovation, including entrepreneurship, corporate governance, finance, economic development, intellectual property, antitrust, and bankruptcy, and serves on Hoover's Property Rights Task Force. He has conducted work that is both adverse to and in support of both Monsanto and DuPont.

Geoffrey A. Manne is Lecturer in Law at Lewis \& Clark Law School in Portland, Oregon, and Executive Director and Founder of the International Center for Law \& Economics, a global think tank founded in honor of economist Armen Alchian and committed to promoting an evidence-based, international discourse on issues of regulatory policy, rooted in the application of price theory, law and economics, and new institutional economics.

Michael E. Sykuta is Associate Professor in the Division of Applied Social Sciences, College of Agriculture, Food and Natural Resources, at the University of Missouri-Columbia, an academic affiliate of the International Center for Law \& Economics, and Director of the Contracting and Organizations Research Institute. CORI is dedicated to the study of the organization and structure of economic enterprise and of the effects of legal, political, social, and economic institutions on the structure and performance of economic organizations.

Joshua D. Wright is Assistant Professor at George Mason University School of Law and Director of Research at the International Center for Law and Economics. His research focuses on antitrust law and economics, consumer protection, contracts, and the intersection of intellectual property and antitrust. 